\title{
THE EFFECT OF BREASTFEEDING BOOSTER FOR BREASTFEEDING MOTHERS IN PEKALONGAN REGENCY
}

\author{
Lia Dwi Prafitri ${ }^{1)}$, Nina Zuhana ${ }^{2)}$, Wahyu Ersila ${ }^{3)}$ \\ Email: L02Prafitri@gmail.com \\ 1,3Prodi Sarjana Fisioterapi Universitas Muhammadiyah Pekajangan Pekalongan \\ Jl Raya Ambokembang No.8 Pekalongan \\ ${ }^{2}$ Prodi Diploma Tiga Kebidanan Universitas Muhammadiyah Pekajangan Pekalongan Jl Raya \\ Ambokembang No.8 Pekalongan
}

Article Information

Received:

May 16, 2019

Revised:

December 23, 2019

Accepted:

January 19,2020

Available online:

January 23,2020

\begin{abstract}
Exclusive breastfeeding is given since the baby is born until the age of two years. Increasing Human Resources by increasing the understanding and knowledge of mothers in giving breast milk was needed to support breastfeeding. Education on breastfeeding booster was expected to help mothers successfully breastfeed. The purpose of this study was to determine the effect of the breastfeeding booster package for breastfeeding mothers in Pekalongan Regency. This research used a Quasi Experiment research design with One Group Pretest and Posttest Design. The population in this study were all breastfeeding mothers in Pekalongan Regency in 2018. This study was conducted in September 2018 to August 2019, with non-probability sampling techniques using cluster sampling with a sample size of 79 respondents. Data analysis in this research was the Wilcoxon test. The results showed a p-value of $0.000(<0.05)$; this means that there is an effect of the breastfeeding booster package for nursing mothers. Public Health Centre was expected to be able to support and facilitate health workers, especially midwives, in providing information to breastfeeding mothers about the importance of breastfeeding booster packages to improve the quality and quantity of breast milk.
\end{abstract}

Keywords: breastfeeding booster, Breastfeeding Mothers

\section{Introduction}

Sustainable Development Goals (SDGs) are a continuation of the Millennium Development Goals (MDGs) global goals that ended in 2015. The Ministry of Health of the Republic Indonesia stated that in the SDGs program the national health system target of the third goal, that in 2030 will reducing maternal mortality (MMR) less than 70 per 100,000 live births, lowering Neonatal Mortality Rates to 12 per 1,000 live births and Child Mortality Rates 25 per 1,000 live births, reducing one-third of premature deaths due to infectious diseases through prevention and care, and promoting mental health and well-being. ${ }^{[1]}$

One of the efforts made to obtain children with excellent growth and development is to exclusively breastfeed until the baby is six months old, and continued until the baby is 24 months old. Therefore, mothers must be prepared to be able to breastfeed properly. It was part of an effort to improve human resources. Through these efforts, will produce healthier babies and children so that it will reduce morbidity and infant mortality while improving the quality of human resources concerned. ${ }^{[2]}$ 
Knowledge and understanding of breastfeeding are essential for breastfeeding mothers, such as the advantages and benefits of breastfeeding, breastfeeding techniques, and obstacles during breastfeeding. In postpartum mothers with cesarean section, breastfeeding is not an activity that occurs automatically. In such conditions, mothers need motivation and need to know the perspective of breastfeeding. Lin et al. (2008) stated that the knowledge and skills of breastfeeding affect the mother's self-confidence. ${ }^{[3]}$

Breastfeeding Booster is an additional supplement for breastfeeding mothers that can function as an increase in the amount of the quantity and quality of breast milk. There were three other factors influencing breastfeeding booster that must be considered by all breastfeeding mothers, namely Mood Booster, where mothers must be in a relaxed condition, not under pressure and getting enough rest. Food Booster, i.e. breastfeeding mothers must consume enough nutritious food that can make abundant breast milk production. Finally, Confidence Booster is a belief that when breastfeeding mothers must have confidence that breast milk given to babies will be enough or even more than enough. ${ }^{[4]}$ One of the intervention studies by Dharmawati, Rustina, and Sabri (2008) found that an increase in early breast milk expenditure through a combination of areola massage with rolling massage for mothers in Pamulang and Cikupa Public Health Centers in Banten. However, the study has not yet seen the effectiveness of interventions on the production of breast milk. ${ }^{[5]}$

Providing education about breast milk boosters is expected to be able to help mothers succeed in caring. Successful breastfeeding starts with proper breastfeeding. It can achieve using the BREAST formula. BREAST stands for B (Body Position), R (Response), E (Emotion), A (Anatomy), S (Suck) and T (Time). ${ }^{[6]}$ The purpose of this study was to know the effectiveness of breastfeeding booster packages for pregnant women in
Pakalongan Regency. Based on the explanation, We were interested in discussing "Breastfeeding Booster Education Package for Breastfeeding Mothers in Pekalongan Regency".

\section{Method}

Design of this research used a Quasiexperiment with one group pretest and posttest design. The population used was all breastfeeding mothers in Pekalongan regency. The sample obtained 79 respondents who met the inclusion criteria, namely breastfeeding mothers who were cooperative and willing to be respondents, physically and mentally healthy, reading and writing bias. This study was conducted to determine the effect of the breastfeeding booster package on the knowledge and motivation of breastfeeding mothers in Pekalongan Regency.

Data normality test used the Kolmogorov Smirnov test because the sample in this study was more than 50; this test was carried out on the variables of knowledge and motivation. The results obtained from the test show all data obtained were not normal with $\mathrm{p}$-value $=$ $0.000(<0.05)$, so the data was analyzed using the Wilcoxon test to determine the effect of the breastfeeding booster package for breastfeeding mothers in Pekalongan Regency.

\section{Results and Discussion}

a. Breastfeeding Mothers' Knowledge

Table 1 Frequency Distribution of Breastfeeding Mothers Knowledge Before and After being given Breastfeeding Booster Package in Pekalongan Regency

\begin{tabular}{lcccc}
\hline $\begin{array}{c}\text { Breastfeeding } \\
\text { Booster } \\
\text { Knowledge }\end{array}$ & \multicolumn{2}{c}{ Before } & \multicolumn{2}{c}{ After } \\
\cline { 2 - 5 } & f & $\%$ & f & $\%$ \\
\hline $\begin{array}{l}\text { Sufficient } \\
\text { Knowledge }\end{array}$ & 46 & 58.2 & 5 & 6.3 \\
$\begin{array}{l}\text { Excellent } \\
\text { Knowledge }\end{array}$ & 33 & 41.8 & 74 & 93.7 \\
$\quad$ Total & $\mathbf{7 9}$ & $\mathbf{1 0 0}$ & $\mathbf{7 9}$ & $\mathbf{1 0 0}$ \\
\hline
\end{tabular}


The findings obtained that there was an increase in knowledge after being given the breastfeeding booster package. It was indicated that the application of the booklet method and demonstration of oxytocin massage could effectively increase the mother's knowledge about breastfeeding boosters. The use of booklets and demonstrations can make it easier for breastfeeding mothers to be able to understand material and information related to breastfeeding boosters. Based on the results of the study, it can be seen that an increase in knowledge about breastfeeding booster was almost entirely (93.7\%) after a posttest was carried out regarding breast milk booster. An increase in knowledge in nursing mothers is obtained by providing health education about breast milk boosters.

Health education about breastfeeding booster aims to provide information to breastfeeding mothers about understanding up to materials to increase breast milk production. By providing information, it was expected that breastfeeding mothers' knowledge increased to excellent knowledge category. Another opinion defines health education as a form of education or to enhance knowledge, attitudes and behaviours that support. ${ }^{[7]}$ The increased knowledge was also likely due to the presence of booklets and demonstrations considered more exciting and made breastfeeding mothers interested to learn and understand about breastfeeding boosters.

Increased knowledge in breastfeeding mothers after being given a breastfeeding booster package, mothers expected to be able to breastfeed their babies exclusively and up to 2 years. Following Lestari (2013), there was a relationship between the level of mother's knowledge about breastfeeding and exclusive breastfeeding. ${ }^{[8]}$

A lack of information caused respondents with sufficient knowledge about breastfeeding boosters before being given breastfeeding booster packages. Lestari et al. (2013) stated that the lack of knowledge could be influenced by internal factors such as lack of interest in finding information and the importance of exclusive breastfeeding; while from external factors, the family has less role in motivating mothers to breastfeed. ${ }^{[8]}$

The information obtained by respondents came from friends, relatives, health workers and the media relatively few. Information about breast milk booster is essential for breastfeeding mothers to help mothers in increasing the quality and quantity of breast milk production. According to Sungkar (2010) in Anjasmara et al. (2015), increasing maternal knowledge can be increased by various types of information media and providing education. One of the efforts that can be done is through counselling so that mothers get information. ${ }^{[9]}$

Many mothers did not know about breastfeeding booster. Breastfeeding mothers often got the wrong understanding; for example, there was no need to use a breast milk booster when breastfeeding because breast milk can come out by eating large portions. Another reason was that breastfeeding mothers find it challenging to get breastfeeding boosters. These reasons should not make breastfeeding mothers not using breastfeeding boosters.

According to Chopra et al. (2011), respondents who had low knowledge were influenced by lack of information exposure. Health workers play an essential role in providing adequate information on improving maternal knowledge. The knowledge provided by health workers is adjusted to the conditions of the community and the need for support from the Hospital program. ${ }^{[10]}$ 
b. Breastfeeding Mothers' Motivation

Table 2 Frequency Distribution of Breastfeeding Mothers Motivation Before and After being given the breastfeeding Booster Package in Pekalongan Regency

\begin{tabular}{lcccc}
\hline \multirow{2}{*}{ Motivation } & \multicolumn{2}{c}{ Before } & \multicolumn{2}{c}{ After } \\
& $\mathbf{f}$ & $\mathbf{\%}$ & $\mathbf{f}$ & $\mathbf{\%}$ \\
\hline $\begin{array}{l}\text { High } \\
\text { Motivatio }\end{array}$ & 43 & 54.4 & 45 & 57 \\
$\begin{array}{l}\text { Low } \\
\text { Motivation }\end{array}$ & 36 & 45.6 & 34 & 43 \\
$\quad$ Total & $\mathbf{7 9}$ & $\mathbf{1 0 0}$ & $\mathbf{7 9}$ & $\mathbf{1 0 0}$ \\
\hline
\end{tabular}

Based on the above table, it can be seen that motivation before and after breastfeeding booster packages given to breastfeeding mothers has increased from $54.4 \%$ to $57 \%$. The existence of health education might influence increased. Health education is an intrinsic factor that a person had because information can give impetus to someone to do something. Health education is also one of the interventions or efforts directed at changing breastfeeding mothers' behaviour so that it is conducive to breastfeeding. ${ }^{[1]]}$

The results of this study were in line with Agustina (2018), which stated that respondents who were given health education increased from before getting health education had a low motivation of $60 \%$, and after getting health education had increased to high motivation by $66.7 \% .^{[12]}$

According to Machfoedz \& Zein (2005) in Retnani (2016), predisposing factors, one of which is motivation is a factor that can influence health behaviour. Motivation can affect behaviour because motivation is an impulse in a person to do certain activities. The findings in this study were known to have a high motivation before, and increased after breastfeeding booster packages was given. The motivation of breastfeeding mothers in using breast milk booster may be influenced by several factors, such as internal factors, namely physical, mental, age, desire in self, self-management and level of knowledge. While from external factors, such as the environment, reinforcement/strength and the media used when conducting this research. ${ }^{[13]}$

The environment had a role in motivating breastfeeding mothers to use breastfeeding boosters. The environment that is less supportive and not conducive will make breastfeeding mothers experience problems such as in the case of taking care of homework often makes mothers feel stressed to interfere with their physical health. While the social environment, such as the role of the closest people and health workers significantly affect breastfeeding mothers.

The results of Nawawi's study (2012) showed that the motivation of health workers had a significant effect on the performance of health centres in health services. ${ }^{[14]}$ Health workers have an essential role in motivating breastfeeding mothers and providing information about breastfeeding booster packages. From the results of the study, breastfeeding mothers had responded about breastfeeding boosters that were difficult to obtain, hassle, and were lazy to consume because they did not like it. Respondents' understanding of breastfeeding booster was still low so that it can result in the use of breastfeeding booster, which was very beneficial for breastfeeding mothers.

c. The Effect of Breastfeeding Booster Package on Breastfeeding Mothers' Knowledge

Table 3 Results of Analysis on the Effect of breastfeeding Booster Packages on Breastfeeding Mothers's Knowledge in Pekalongan Regency

\begin{tabular}{lccl}
\hline Knowledge & \multicolumn{3}{c}{ Results } \\
\cline { 2 - 4 } & Mean & Zscore & p-value \\
\hline Pretest & 73.94 & $-6.024^{\mathrm{a}}$ & 0.000 \\
Posttest & 84.84 & & \\
\hline
\end{tabular}


The results showed a change in the mean value before being given health education by $73.94 \%$ to $84.84 \%$ after getting health education. The change in value looks higher than the previous value. Based on the Wilcoxon Test results obtained Zscore value of -6.024 and $p$-value of 0.000 . $\mathrm{P}$-value $<0.05$, which means that Ho is rejected, so it can be concluded that there is an effect of the breast milk booster package on the knowledge of nursing mothers.

Knowledge of breastfeeding mothers had increased after receiving the breastfeeding booster package. These findings accord with the statement of Perinasia (2010), which states that breastfeeding booster education can be able to help mothers succeed in breastfeeding their babies. ${ }^{[6]}$ The breastfeeding booster package in this study contains information on causes of decreased breast milk production, strategies to increase breast milk production, signs of baby adequacy of milk, food and drinks that are believed to be breast milk booster, and oxytocin massage. In this study, one of the breastfeeding booster packages given was through a booklet. It was expected that with the breastfeeding booster booklet could convey information to breastfeeding mothers about breastfeeding booster

Another supporting study conducted by Adawiyani (2013) which state that the educational method provides significant benefits in the form of anemia booklets can increase knowledge in pregnant women. ${ }^{[15]}$ Isyti'aroh et al. (2015) stated that breast education packages that have been given increase knowledge, which in turn will undergo an internalization process until awareness arises to apply that knowledge. ${ }^{[16]}$

Chopra et al. (2011) also stated that knowledge and opinions about the relationship between the health of infants with breastfeeding were influenced by the level of education and sources of written information obtained. ${ }^{[10]}$

Health education can change the knowledge of breastfeeding mothers, with the presence of a booster package in the form of counselling, distribution of booklets, demonstrations of oxytocin massage and breastfeeding booster products obtained the results of increasing mothers' knowledge. Ho and McGrath (2016) explained that the provision of health education regarding education packages in the form of booklets was able to change the knowledge and attitudes of young women in Taiwan about breastfeeding infants. Although it was unknown whether the young girls receiving the intervention will later breastfeeding her baby, but her research proves that teens have a positive attitude towards breastfeeding. ${ }^{[17]}$

d. The Effect of Breastfeeding Booster Package on Breastfeeding Mothers' Motivation

Table 4 Results of Analysis on the Effect of breastfeeding Booster Packages on Breastfeeding Mothers's Motivation in Pekalongan Regency

\begin{tabular}{lccl}
\hline Motivation & \multicolumn{3}{c}{ Results } \\
\cline { 2 - 4 } & Mean & Zscore & p-value \\
\hline Pretest & 91,01 & $-7.724^{\mathrm{a}}$ & 0.000 \\
Pos test & 110,3 & & \\
\hline
\end{tabular}

The results of the study stated that there was an effect of the breastfeeding booster package on the motivation of breastfeeding mothers $(\mathrm{p}$-value $=0.000)$. Retnani (2016) stated that health workers influenced maternal motivation in exclusive breastfeeding. ${ }^{[13]}$ According to Zakaria (2005) in Retnani (2016), motivation helped a person shape his behaviour and help achieve satisfaction after all needs and desires can be fulfilled. Moreover, a mother needs the confidence to be able to breastfeed her baby correctly. ${ }^{[13]}$ 
Maulida et al. (2015) stated that there was a relationship between economic level and mother's motivation in breastfeeding. The close relationship was in the sharp category with a value of 0.662 , so it was advisable to do counselling and coaching on the importance of breastfeeding so that it motivates mothers to give exclusive breastfeeding to their babies. ${ }^{[18]}$

Retnani (2016), stated that one of the factors that influence extrinsic motivation was the environment, where there was a role of health workers to participate in influencing the motivation of breastfeeding mothers to breastfeed their babies for six months. The role of the health worker was one form of interaction carried out in providing tangible assistance to increase the motivation of mothers in exclusively breastfeeding. ${ }^{[13]}$ Thus, breastfeeding mothers need to use breastfeeding booster to improve the quality and quantity of breast milk. Exclusive breastfeeding for six months and continued for up to 2 years can be successful in creating a healthy and quality generation.

\section{Conclusion}

The results showed a p-value $=0.000$ $(<0.05)$, which means there is an effect of breastfeeding booster package on the knowledge and motivation of breastfeeding mothers in Pekalongan Regency. Midwives were expected to be able to provide information about breastfeeding booster packages for breastfeeding mothers which could improve the quality and quantity of breast milk. Health Centre expected to be able to provide support and facilitate health workers (midwives) in providing information to breastfeeding mothers.

\section{Acknowledgement}

Our gratitude to the Institute for Research and Community Service of STIKES Muhammadiyah Pekajangan, Regional Civil Service Agency of Pekalongan
Regency, Health Office of Pekalongan Regency and Health Centres in Pekalongan Regency.

\section{Reference}

[1] Kemenkes RI. Profil Kesehatan Indonesia tahun 2014. Jakarta : Kemenkes RI. 2015.

[2] Anggrita, K. Hubungan Karakteristik Ibu Menyusui terhadap Pemberian ASI Eksklusif di Wilayah Kerja Puskesmas Medan Amplas Tahun 2009.Karya Tulis Ilmiah.Fakultas Kedokteran Universitas Sumatera Utara. Medan. 2010.

[3] Lin, Chien-Hui, dan Su-Chen, K. Evaluating effect of prenatal breastfeeding education program on woman with cesarean delivery in Taiwan. 2008. Journal of Clinical Nursing. 17 (21), 28382859.

[4] Kompas. Berita Baik untuk Ibu Menyusui, Kini Asi Booster dapat Dinikmati dengan Rasa yang Nikmat. 2016.

[5] Dharmawati, Rustina,Y., dan Sabri,L.Efektifitas Kombinasi Aerola Massage dengan Rolling Massage terhadap Pengeluaran ASI secara dini pada Ibu Nifas di Puskesmas Pamulang-Banten. (Tesis, tidak dipublikasikan). FIK UI, Depok. 2008.

[6] Perinasia. Bahan Bacaan Manajemen Laktasi. Jakarta: Perinasia. 2010.

[7] Bernaix LW, Beaman ML, Schmidt CA, Harris JK and Miller LM. Success of an educational intervention on maternal/newborn nurses' breastfeeding knowledge and attitudes. 2010. Journal Obstet Gynecol Neonatal Nurs 39(6), 658666

[8] Lestari D, Zuraida R, Larasati TA.Hubungan tingkat pengetahuan ibu tentang Air Susu Ibu dan pekerjaan ibu dengan pemberian ASI eksklusif di kelurahan fajar bulan. 2013. Jornal of lampung University.2:4. 
[9] Anjasmara, J., Susanti, H. D., dan Pratiwi, I. D. Hubungan Tingkat Pengetahuan Ibu tentang Inisiasi Menyusui Dini (IMD) dengan Partisipasi Ibu Melakukan IMD. 2015. Surya 07 (01): 1-10.

[10] Chopra, Kalia, Raman. Knowledge and opinions mothers of Breasfeeding. 2011. Nursing and Midwifery Research 7 (5).

[11] Notoatmodjo, S. Kesehtan Masyarakat. Jakarta: Rineka Cipta. 2010.

[12] Agustina, I. The Effectiveness of Heatlh Education of Breasfeeding Preparation on primigravida mother's motivation of provide Exclusivation. 2018. Jurnal Ners dan Kebidanan, 5(1) 74-78

[13] Retnani, A. D.Hubungan Peran Petugas Kesehatan dengan Motivasi Ibu dalam Pemberian ASI Eksklusif di Desa Wonorejo Kecamatan Kencong Kabupaten Jember. Skripsi. Universitas Jember. 2016.

[14] Nawawi, M. Pengaruh motivasi dan kompetensi tenaga kesehatan terhadap kinerja pusat kesehatan masyarakat. Jurnal Mimbar.2012. Vol XXVIII No.1 (Juni, 2012) : 93 102

[15] Adawiyani, R. Pengaruh pemberian booklet anemia terhadap pengetahuan, kepatuhan minum tablet tambah darah dan kadar hemoglobin ibu hamil.Caliptra: Jurnal ilmiah mahasiswa universitas Surabaya.2013. 2:2

[16] Isyti' aroh, Nizmah, N., dan Rejeki,H. Paket Edukasi Breast dan Pengaruhnya terhadap Kesuksesan Ibu Primipara dalam Menyusui. 2015. Prosiding The 2nd university Research Coloquium.

[17] Ho, YJ and McGrath JM. Effectiveness of a Breastfeeding Intervention on Knowledge and Attitudes Among High School Students in Taiwan. Journal of
Obstetric, Gynecologic \& Neonatal Nursing. 2016. 45(1), 71-77.

[18] Maulida, H. Afifah E, Pitasari D.Tingkat ekonomi dan motivasi ibu dalam pemberian ASI eksklusif pada bayi usia 0-6 bulan di Bidan praktek Swasta (BPS) ummi latifah argomulyo, Seday Yogyakarta.Jurnal Ners dan kebidanan Indonesia. 2015.3(2): 116-122 